\title{
Yoksulluk ve Suç İlişkisinin Sosyolojik Analizi: Bir Referans Çerçevesi (Elazı̆̆ Örneği)
}

\author{
Muhammet FIRAT ${ }^{1}$
}

Öz: Sosyal yaşantıda suça etki eden birçok faktörden söz edilebilir. Ekonomik durum ve yoksulluk, suç üzerinde oldukça etkili olan unsurların başında gelmektedir. Birçok sosyolog, kriminolog ve ekonomist, suç ile yoksulluk arasında etkisel bir ilişkinin olduğunu kabul etmektedir. Bu açıdan tüm sosyal bilimlerin ilgi alanına giren suç, özelikle nedenleri ve sonuçları açısından ekonomik boyutu göz ardı edilemeyecek derecede önemli bir olgudur. Ancak bu çalışma, suç ile yoksulluk arasında kesin bir nedensellik ilişkisi yerine, yoksulluğun, suç işlemede pozitif etki ettiğine kanaat getirmiştir. Bu minvalde suç ile yoksulluk ilişkisinin ortaya çıkarılması amacıyla Elazı̆̆ İlinin yoksulluk haritasında, yoksul olarak bilinen Aksaray, Hicret ve Sanayi Mahallelerinde ikamet eden daha önce çeşitli suçlardan cezaevine girmiş 29 birey ile anket çalışmasından hareket etmiştir. Öte yandan, alanda elde edilen gözlemler çalışmanın şekillenmesinde etkili olmuştur. Bireylere cezaevine girmeden önce ve cezaevinden çıktıktan sonraki genel durumları, işledikleri suçlar ve ekonomik durumları ile ilgili sorular sorulmuştur. Elde edilen veriler yorumlanarak yoksulluk ile suç arasındaki ilişkinin irdelenip belirlenmesi amaçlanmıştır.

1 Arş. Görv. Fırat Üniversitesi, İnsani ve Sosyal Bilimler Fakültesi, Sosyoloji Bölümü. muhammetfirat@firat.edu.tr 
Anahtar Kelimeler: Yoksulluk, Suç, Sosyo-ekonomik durum, Yoksulluksuç ilişkisi, Elazığ.

\section{Giriş}

Yirminci yüzyılın sonlarında, insanlığın yüz yüze kaldığı en önemli beşeri ve toplumsal bir olgu olarak gündemi işgal eden yoksulluğun suçla ilişkisi irdelendiğinde, anlamlı bir ilişkinin var olup olmadığ 1 hususu akla gelen ilk sorulardandır. Çünkü suç istatistiklerine bakıldığında, suç işleyen bireylerin çoğunluğunun yoksul olduğu bilinmektedir. Kaybedecek çok şeyi olmayan bireylerden oluşan yoksulların suç işlemeye daha yatkın oldukları düşünülmektedir. Dolayısıyla, yoksul bireyler, hayat şartları iyi olmayan ve suç teşkil eden hayat tarzıyla devamlı temas halinde olan bölgelerde yaşamaktadır. Bu amaçla yoksulluğun çok olduğu yerlerde suç oranlarının yüksek olup olmadığı incelenmesi gereken hususlardan biridir.

"Suç, hukuk kurallarının toplum için zararlı ve tehlikeli görerek yasakladığ 1 ve cezai yaptırıma bağladığ 1 eylem” olarak tanımlanabilir (Ayhan ve Çubukçu, 2007: 31). İnsanların neden suç işledikleri, kamu gücü tarafından cezalandırılma riskine karşın neden suça yöneldikleri her zaman merak konusu olmuştur. Bugüne kadar suçun nedenlerini ortaya çıkarmaya yönelik çok sayıda araştırma yapılmıştır. Bu araştırmaların büyük çoğunluğu ya özel bir suçu, ya da suç işlenmesinde etkili olan bütün faktörleri inceleme konusu yaparken, özel bir etken ile suç arasındaki ilişkiyi inceleyen çalışmaların daha az olduğu bilinmektedir. Suç üzerinde etkili olabilecek faktörler arasında yaş, cinsiyet gibi demografik nedenler ve yoksulluk gibi sosyo-ekonomik unsurlardan da söz edilebilir (Dinler ve İçli, 2012: 2). Bu bağlamda yoksulluk son yılların en önemli sorunlarından birini oluşturmaktadır. Özellikle küreselleşme süreciyle beraber gelir dağılımındaki bozulma ve yoksulluk önemli bir sorun olarak karşımıza çıkmaktadır. Yoksulluk içindeki bireylerin, kaybedecekleri çok az şey olduğundan, bu bireylerin suç işleme eğilimleri daha fazla olabilmektedir (Mehlum \& Moene \& Torvık, 
2005: 325-340). Bu nedenle yoksulluğun yüksek olduğu kesimlerde suç oranının artması kaçınılmaz olabilir.

Marksist kriminolog W.A. Bonger, Suçluluk ve Ekonomik Şartlar (1916) isimli çalışmasında kapitalist sistemin bireyleri açgözlü ve bencil olmaya ittiğini ileri sürmektedir. Bonger'e göre, suç alt sınıflarda yoğunlaşmaktadır, çünkü adalet sistemi fakir olan bireyleri suçlu hale getirirken, zengin olan bireylerin kendi bencil isteklerine ulaşabilmeleri için yasal olanakları onlara sunmaktadır. Bu açıdan Bonger, suçun zenginlikle, ekonomik iyileştirmelerle ortadan kaldırılabileceğini ileri sürmektedir (Vold \& Bernard \& Snipes, 2001: 253). Bu minvalde yoksulluk sarmalındaki bireylerin kendine özgü yaşam tarzları, damgalı mekânları ve dışlanmaları onların hukuk dışı eylemlere yönelimlerini arttırmaktadır. Ayrıca ekonomik olanakların yetersiz olduğu durumlarda, bireyler ihtiyaçlarını giderebilmek adına suç islerler.

Suç üzerine yapılan çalışmalarda; modernleşme, sanayileşme, kentleşme, aile yapısı, akran grubu, kültürel yapı, medeni durum, öğrenim düzeyi, din, yerleşim yeri, işsizlik ve yoksulluk gibi daha sayamadığımız çok sayıda değişkenin konu olduğu bilinmektedir. Bu değişkenler arasında yoksulluk ve suç ilişkisini konu edinen bu çalışma, yoksulluk ile suç arasında bir ilişkinin var olup olmadığı, yoksulluk ile suç arasında bir ilişki varsa, bu ilişkinin boyutlarını irdelemektedir.

\section{Yoksulluk}

Dar anlamda yoksulluk, maddi nitelikteki mahrumiyetlerden dolayı kaynaklara ve üretim faktörlerine erişememe, böylece asgari yaşam düzeyi sürdürecek gelirden yoksun bulunma hali, güncel olanaklara ulaşmada sinırlılık, varlıktan yoksulluk, geçinmede güçlük çekme geçimi için yeterli paraya sahip olmamadır (Aydın, 2007: 16).

Yoksulluk için araştırmacılar arasında tercih edilen iki farklı yaklaşım söz konusudur: mutlak yoksulluk, göreli yoksulluk. Yoksulluk genel olarak bir halkın ya da onun belirli bir kesiminin asgari yaşam düzeyini sürdürebilmek için gıda, giyim ve barınak gibi sadece en basit 
ihtiyaç maddelerini karşılayabilmesi olgusudur. Buna mutlak yoksulluk da denmektedir. (Uzun, 2003: 156). Cömertler (2004) Dünya Bankası'nın tanımlamasına göre, mutlak yoksulluk günlük geliri $2400 \mathrm{k} / \mathrm{cal}$. besini almaya yeterli olmayan insanların durumunu ifade etmektedir. Mutlak yoksulluk sınırı az gelişmiş ülkeler için kişi başına günde 1 dolar, Latin Amerika ve Karaibler için 2 dolar, Türkiye'nin de dâhil edildiği Doğu Avrupa ülkelerinin de içinde bulunduğu gurup için 4 dolar, gelişmiş sanayi ülkeleri için 14.40 dolar olarak belirlenmiştir (Cömertler'den akt., Aydın, 2007: 17 ). Birey bu standartlar altında yaşamını sürdürüyorsa, o bireyin yoksul olduğu söylenebilir.

Bununla birlikte bu standartların yoksulluğu belirlemede uygun olmadığı, bireyin yoksulluğunun belirlenmesinde göreli yoksulluk kavramının kullanılmasının daha uygun olduğunu savunanlar, yoksulluğun kültürel olarak tanımlanmasını ve evrensel bir yoksulluk standard1nın ölçülmemesi gerektiğini ileri sürmektedirler (Giddens, 2008: 386). Yani; yoksulluk araştırmaları yapılırken yerleşim yeri, imkân ve olanaklara ulaşılabilirlik incelenir. Bir sosyal grup veya bireyin yoksulluğunun diğer sosyal grup ve bireylerle karşılaştırılıp analiz edilmesi sonucu göreli yoksulluk dediğimiz yoksulluk belirlenir. Yeterli ve dengeli beslenmek insanların hayatını sağlıklı bir şekilde devam ettirebilmesi için gereklidir. Ancak buna ek olarak besin tüketiminin yanında tüketilmesi gerekli olan toplumsal kültürel gereksinimler de mevcuttur. İşte bu gereksinimleri karşılanabilirliği diğer bireyler ya da hane halkları ile karşılaştırmalı olarak analiz edildiğinde göreli yoksulluk sonuçlarına ulaşılır (Işık, 2007: 17).

Genellikle para veya gida yokluğunun belirtisi olarak tabir olunan yoksulluğun sınırlarını genişletmek mümkündür. Kültür, hizmet, inanç yoksulluğu, yoksulluğun geniş yelpazesi içerisinde kalan kavramlardır. Ancak araştırma konusu açısından, yoksulluk en çok bireylerin beslenme, barınma gibi temel ihtiyaçlarının karşılanamaması olarak kullanılmaktadır. Yoksulluk tanımlanırken de bu kriterlerden hareket edilmektedir.

Ancak yoksulluğun gelir düzeyiyle sınırlı tanımlarını kabul etmeyen Amartya Sen, yoksulluğu özellikle 'yapabilirlik' kavramı yardımıyla 
açıklamaktadır. Yapabilirlik, açlık, sağlıksızlık, cahillik, kötü barınma koşulları gibi, her insanın mutlaka kaçınmak isteyeceği durumlardan kaçınabilme yetisi olarak tanımlanmaktadır. Bu bağlamda 'yapabilirlikten yoksunluk', yoksulluğun tanımı olarak ortaya çıkmaktadır (Buğra, 2005). Yoksulluğun belirlenmesinde temel ölçüt, bireyin gelir düzeyi ile temel gereksinimlerini karşılama yeterliliğidir. Buna ek olarak, yeterli öğrenim görmemiş olmak, salt bedensel güce dayalı vasıf gerektirmeyen işte çalışmak veya işsizlik, iş bulmak veya diğer ekonomik nedenlere dayalı olarak göç etmiş olmak yoksulluğun çerçevelendirilmesinde önemli ölçütler kabul edilmiştir (Dinler ve İçli, 2012: 3).

\section{Suç}

Suç farklı dönemlerde, farklı bölgeler tarafından farklı şekillerde tanımlanmıştır. Zira her toplumda değişen ölçülerde var olmuş ve var olmaya da devam edecek olan evrensel ve genel bir olay olarak suç, farklı kültürlerin ve toplumlarına yapısına göre değişen bir görünüm sergilemektedir. Bu açıdan bireylerin içindeki ihtiraslarla birlikte toplum içinde yaşamanın ortaya çıkardığ çeşitli sosyal çelişkiler ve uyumsuzluklar var oldukça; suç olgusu da toplumda her zaman kendine yer bulacaktır (Dönmezer, 1994: 49).

Bu bağlamda toplumun devamı ve bütünleşmesi, toplumu meydana getiren insanların, sosyal yaşam içerisinde oluşturulan din, ahlak, hukuk kurallarına uygun hareket etmeleriyle mümkün olabilmektedir. Toplumsal kurallara riayet etme halkın birlikte yaşamasını temin ederken, bu kurallardan sapma, toplum içinde yaşayan insanların rahatsız olmasına neden olarak toplumun devamını ve bütünlüğ̈̈nü zedelemektedir. Bu çerçeveden hareketle, genel olarak norm ihlali durumu şeklinde tanımlanan suç, gelişmiş ülkelerde olduğu gibi gelişmekte olan ülkelerde de, kentlerde olduğu gibi kırsal alanlarda da yaşanan evrensel bir olgudur (Dönmezer,1994: 61).

Sosyolojik anlamda suç kavramı toplumda var olan normlardan sapma olarak tanımlanmaktadır. Sapma davranışı gibi suç toplumun değer ve normlarından sapan eylemdir. Ancak suç, kanun koyucular 
tarafından ceza yaptırımı belirlenmiş olduğundan dolayı diğer sapma davranışlarından ayrılmaktadır (Kızılçelik ve Erjem, 1994: 402). Genel bir tanım yapılacak olunursa, topluma zarar verdiği ya da tehlikeli olduğu yasalar tarafından kabul edilen ve belirtilen eylemler "suç" olarak nitelendirilebilir.

Suç olgusunun genelliğine ek olarak aynı zamanda nisbiliği yani göreceli oluşu da bir diğer noktadır. Suç, işlendiği mekâna, işleniş sebebine, işleyen kişinin içinde bulunduğu psikolojik duruma, yaşına göre değişmektedir (Dönmezer, 1994: 49).

$\mathrm{Bu}$ çerçevede suçluluğun neden bazı toplumsal yapılarda diğerlerinden daha sık işlendiği, hangi sosyal, ekonomik ve kültürel şartlarda, hangi tür sosyal ilişkilerin hâkim olduğu yapılarda suçluluğun arttığ 1 ya da azaldığı hep merak konusu olmuştur. Toplumsal yapı içinde kişileri suça iten nedenler ancak bu konuyu kapsayan detaylı bilimsel analizlerin periyodik olarak yapılması ile büyük ölçüde anlaşılabilir. Hızlı bir değişme süreci yaşayan toplumumuzda, suç probleminin bilimsel yönden incelenmesi ve suça neden olan unsurların belirlenmesi en azından, ilgili kurumlar tarafından gerekli önlemlerin alınmasını kolaylaştıracaktır (İçli, 1993:2).

İster ahlaki, ister biyolojik, isterse toplumsal bağlamda ele alınsın, suçun nedenlerini genel olarak dört baslık altında değerlendirebiliriz: "Biyolojik Nedenler, Psikolojik Nedenler, Sosyolojik Nedenler, Sosyo-Psikolojik Nedenler” (Sokullu, 2012: 1-3). Bu çerçevede suçun nedenleri arasında şüphesiz ki en geniş kapsamlı olanı sosyolojik nedenlerdir. Siyaset, ekonomi, çevre, kurumlar, arkadaş çevresi, aile, örf ve adetler, din, eğitim, gibi sosyolojik konularla suç arasındaki bağlantıları ortaya koyan çalışmalar mevcuttur (Işık, 2007: 48).

Suç çok karmaşıktır ve bir takım faktörlere göre değişebilir. Suçun işlendiği çevre, suçu işleyenin cinsiyeti, yaşı ve bunun gibi pek çok faktör suçun ortaya çıkısında bağımsız değişkenlerdir. Bu bağımsız değişkenleri şu şekilde sıralamak mümkündür: "Cinsiyet, Yaş, Medeni Durum, Meslek, Öğrenim Durumu, Suçun işlendiği Yer ve işleniş Zamanı, Aile Yapısı ve Aileye ilişkin Özellikler, Ekonomik Düzey”. Tüm 
bu değişkenler suçun niteliğine göre farklılık gösterebilir. Suç incelenirken ve suçla ilgili hüküm verilirken bu değişkenler dikkate alınmak zorundadır (İçli, 1993: 18).

\section{Yoksulluk ve Suç: Bir Referans Çerçevesi}

Suç ve suçla mücadele daha çok sosyologların ve kriminologların ilgisini çekmiş konulardır. Bu alana ekonomistlerin ilgi duyması Gary Becker’in 1968 yılında kaleme aldığı öncü niteliğindeki makale ile başlanmıştır. Buradan hareketle ekonomik bir perspektiften suç olgusunu analiz eden Becker'e göre, kişiler, yaptığı davranışları bilinçli yapar ve davranışlarında az emek ile çok menfaat kazanmak ister. Yapmış olduğu hareket yanlış bile olsa, onun getiri ve götürüsünü hesaplayarak kararını verir. Buradan hareketle niçin bazı insanlar suç işlemeyi tercih ederken, diğerleri kurallara uyarak istediklerine ulaşmaya çalışır sorusu akla gelir. Becker'e göre, bireylerin ihtiyaçları farklılık göstermektedir. Kimisi için önemli olan, diğeri için önemsiz olabilir (Ehrlich, 1996: 43-67). Buradan hareketle suçun, ekonomi faktörü ilişkisine ilaveten, suçun ekonomik eşitsizliklerin bulunduğu toplumsal yapılarla ilişkisi de alınmaktadır.

Bu bağlamda gelişmekte olan ülkelerde meydana gelen ekonomik değişimler suç oranlarını ve suçluluk eğilimini arttırmaktadır. Bu açıdan ekonomik yapıda güvenliğin arttırılması suçluluğun önlenmesi ya da azaltılmasını sağlayacak bir mekanizma olarak düşünülebilir. Sosyal düzen bozukluğu kuramının bugünkü durumunda suç oluşumunu açıklayan faktörlerden birisi yoksulluktur. Yoksul kırsal alanlar şiddet suçunun en yüksek görüldüğü yerlerdir. Çalışmaları sonucunda yoksulluğun hâkim olduğu geçiş bölgesinde suç oranlarına daha fazla rastlandığını belirten Ergun ve Yirmibeşoğlu (2005) bunun nedeninin ekonomik elverişsizlik olduğunu savunmaktadırlar. Ackerman (1998), Gruenewald vd. (2006) ve Wang ve Minor (2002) da yoksulluğu suçla ilişkili değişkenlerden biri olarak kabul etmiştir. En yüksek suç oranlarının ekonomik dezavantajların ve sosyal stresin en çok toplandığ durumdaki küçük şehirlerde görüleceğini savunan Ackerman’a (1998) 
göre suç yoksulluğun bir fonksiyonudur (Çubukçu; Ayhan, 2007: 36). Bu çerçevede yoksulluk ve suç birbiri üzerinde ya doğrudan doğruya ya da dolaylı yoldan etki etmektedir, denilebilir. Zira yoksulluk ve yoksunluk insanların kötü mesken şartlarını ve bu tür ikamet bölgelerine sığınmış olan suçlularla daimi temas halinde bulunmalarına neden olur. Bu temas, yoksul bireylerin yasa dışı eylemlere yönelmelerini kolaylaştırmaktadır.

Öte yandan her ne şekilde engel olunursa olunsun insan, çevresindeki diğer insanlar gibi iyi ortamda hayatını devam ettirmek, çocuklarına daha güzel bir gelecek hazırlamak çabası içine girmektedir. Bu hedefini engelleyecek her şey ona engel olarak görünmekte ve bu engellerden gerek yasal, gerekirse yasal olmayan yollarla kurtulma çabasına girişmektedir. Tahmin edileceği üzere yasal yollarla çıkış bulmak ve hedefe ulaşmak pek kolay olmamaktadır. Bunun yerine isyan, şiddet, yasa dışı yolları kullanarak zengin olma ve hedefe ulaşma duyguları, çok daha sık tercih edilen yol olarak kullanılmaktadır (Farnworth ve Lieber, 1989: 263-274).

Konuya yoksulluk tanımlamalarından yaklaşacak olursak; "Zira yoksulluk, ekonomik bir kategori olmanın yanı sıra, kişilerin içinde yaşadığı, anlamlandırdığı, başa çıkmak için çeşitli yöntemler geliştirdiği toplumsal bir durumdur" (Erdoğan, 2002: 9-10). Bu tanımlamadan hareketle birçok suç teorisi, suçun yoksulluğa paralel olarak arttığını ileri sürmektedir. Bu teorilere göre, dünyada beklentisi olmayan insanlar, beklentisi olanlara göre daha tehlikelidir. Çünkü insanlar iyi bir ortamda yaşıyor ve ihtiyaçları gideriliyorsa, bu imkânlardan yoksun kalmak istemez ve bunu oluşturacak hareket ve davranışlara yönelmezler. Aksi halde, karşılaşacakları olumsuz bir ortam, onları istenmedik bir ortama sürükleyebilir (Farnworth ve Lieber, 1989: 263-274).

Buradan hareketle suçun, yoksul insanlara meşru yollardan elde edilemez maddi malları illegal yollardan elde edebilecekleri bir yol sunduğunu ileri sürebiliriz.

Genellikle tehdit ve güç, suçlulara daha fazla mal elde etmede yardımcı olabilme imkanı sunmaktadır. Bu açıdan birçok yoksul insan için, suç verimi, yakalanma riskinden daha fazla olduğu düşüncesi bu 
tür eylemleri gerçekleştirmeye yol açmaktadır. Böylece, yoksulluk, suç oranlarını artırıcı bir etki meydana getirir. Ancak, suçu etkileyen birçok faktör aynı zamanda yoksullukla ilişkilidir. Örneğin, yüksek işsizlik, kesinlikle yoksulluğu artırmakta ve aynı zamanda, işsizliğin olması ile ilişkili olan depresyon nedeniyle daha fazla suçun işlenmesi durumu ortaya çıkmaktadır (Taylor, 2006: 1).

Ayrıca herhangi bir değişkenin suçun nedeni olarak kabul edilmesi, o değişkene rastlandığı her durumda suçun kendiliğinden ortaya çıkmasını gerektirmektedir. Şöyle ki; yoksullukla suç arasında bir ilişkinin varlığg belirlense bile, yoksulluğun suçun nedeni olduğunu söylemek, yoksulluğun karşılaşıldığ şeceğini kabul etmektir. Yoksullukla suç arasında sıkı bir ilişkinin varlığı dahi, suçun nedeninin yoksulluk olduğunu ortaya çıkarmaz, ancak yoksulluğun suç işlemeye pozitif yönde etki ettiği ortaya çıkarılabilir. İçli (1991) tarafından yapılan araştırmada, kişilerin ekonomik durumlarıyla suçluluk arasında güçlü ve anlamlı ilişki bulunduğu sonucuna varılmıştır. Suçluların yarısından fazlasının yoksul olduğu belirlenmiştir. Yoksullar arasında hırsızlık ve kız kaçırma suçu işleyenler yoksul olmayanlara göre iki kattır (Dinler ve İçli, 2012: 2-4).

Bu ve bunun gibi birçok araştırmanın ışığ 1 altında yoksulluğun suçla ilişkisi incelendiğinde, anlamlı bir ilişkinin var olup olmadığı merak edilen bir durumdur. Zira bu tür araştırmaların sonuçlarına bakıldığında, suç işleyen şahısların çoğunluğu yoksul ve kaybedecek çok şeyi olmayan insanlardır.

\section{Araştırmanın Metodolojisi}

\subsection{Araştırmanın Konusu ve Amacı}

Bu araştırmada suça etki eden birçok faktörden biri olarak yoksulluk değişkeni ele alınmaktadır Bu çerçeveden hareketle bu değişkenler arasında yoksulluk ve suç ilişkisini konu edinen bu çalışma, yoksulluk ile suç arasında bir ilişkinin var olup olmadığı, varsa, bu ilişkinin boyutlarını irdelemektedir. Bu bağlamda araştırmanın amacı da yoksulluk ve suç ilişkisi bir neden-sonuç ilişkisi yerine, bazı suç işleyen bireylerin 
suç işleme nedenleri arasında yoksulluğun ne derece etkili konusunda bir fikir edinebilmektedir.

\subsection{Araştırmanın Evreni, Varsayımı ve Yöntemi}

Araştırma Elazığ İlinin yoksulluk haritasında, yoksul olarak bilinen Aksaray, Hicret ve Sanayi Mahallelerinde ikamet eden daha önce çeşitli suçlardan cezaevine girmiş 29 birey ile anket çalışmasından hareket etmiştir. Öte yandan, alanda elde edilen gözlemler çalışmanın şekillenmesinde etkili olmuştur. Bireylere cezaevine girmeden önce ve cezaevinden çıktıktan sonraki genel durumları, işledikleri suçlar ve ekonomik durumları ile ilgili sorular sorulmuştur. Araştırma kapsamında araştırmayla ilgili hazırlanan anket ve mülakat yöntemi yoluyla çeşitli veriler elde edilmiştir. Bu veriler çalışmanın amacı doğrultusunda öncelikle genel sorulardan daha sonra ise çalışmanın özüne ilişkin özel sorulardan oluşmaktadır.

Araştırma alanın tercih edilmesinde belirlenen mahallelerin Elazığ İlinin en yoksul alanları olarak bilinmesi etkili olmuştur. Bu bağlamda, Elazığ Mamüratil Aziz Yardımlaşma ve Dayanışma Vakfı̉ndan temin edilen, Elazığ İlinin en yoksul bölgelerinde bulunan ve herhangi bir suçtan hüküm giymiş bireyler belirlenmiştir. Bu bağlamda araştırmada evreni olarak Elazığ İli seçilmiş ve belirlenen görüşmecilerin Elazığ İlini temsil edecek yeterlilikte olduğu belirlenmiştir.

Araştırmada yoksulluk göstergeleri olarak, işsizlik, gelir düzeyi gibi unsurlar ele alınmıştır. Öte yandan bu araştırmanın temel varsayımı, bazı suç işleyen bireylerin suç ileme nedenleri, yoksulluklarıdır. Ayrıca bu çalışmada yoksulluk ve suç birbirini etkileyen süreçler olarak ileri sürülmektedir.

\section{Sosyo-Demografik ve Sosyo-ekonomik Yapı Sonuçları ve Bulguların Analizi}

Araştırma kapsamında araştırmayla ilgili hazırlanan anket gözlem yöntemi yoluyla çeşitli veriler elde edilmiştir. Bu veriler çalışmanın amacı doğrultusunda öncelikle genel sorulardan daha sonra ise çalışmanın özüne ilişkin özel sorulardan oluşmaktadır. 
Tablo 1: Katılımcıların cinsiyet dağılımı

\begin{tabular}{lcc}
\hline Cinsiyet & Frekans & Yüzde \\
\hline Erkek & 29 & 100 \\
\hline
\end{tabular}

Kadın ve erkeğin, toplumda üstlendikleri roller, içinde bulunan kültür tarafından şekillendirilir. Cinsiyet rolleri, toplumların sosyal, ekonomik ve kültürel yapısından etkilendiğinden her topluma ve aynı toplum içinde de koşullara göre zamanla değişiklik göstermektedir. Cinsiyet, açıklanmaya çalışılan toplumsal gerçekliği anlama açısından da ayrıca önemli bir etken olarak kabul edilmektedir. Görüşülenlerin tamamı erkektir. Bunda, kadınlara ulaşmada mahremiyetin etkisi ve kadınların katılıma sıcak bakmamaları gibi nedenler etkili olmuştur. Ayrıca alanda cezaevine girip çıkan iki kadın katılımcı tespit edilmiş ve yukardaki nedenlerden dolayı anket çalışması yapılamamıştır.

Tablo 2: Katılımcıların yaş dağılımı

\begin{tabular}{lcc}
\hline Yaş grubu & Frekans & Yüzde \\
\hline $21-30$ & 4 & 13,8 \\
\hline $31-40$ & 13 & 44,8 \\
\hline $41-50$ & 7 & 24,1 \\
\hline $51-60$ & 5 & 17,2 \\
\hline Toplam & $\mathbf{2 9}$ & $\mathbf{1 0 0}$ \\
\hline
\end{tabular}

Katılımcıların yaş dağılım 21 ile 60 arasındadır. Değerlendirme yapılırken yaş grupları dokuzarlı gruplar halinde sunulmuştur. Araştırılan bireyler arasında en büyük yaş grubunu \% 44,8 ile 31-40 arası yaş grubu oluşturmaktadır. Bu grubu 41-50 yaş grubu (\%24,7), 51-60 yaş 
grubu $(\% 17,2)$ ve $21-30$ yaş grubu $(13,8)$ izlemektedir. Araştırmada orta yaş grubu bireylerin çoğunlukta olduğu görülmektedir.

Tablo 3: Katılımcıların medeni durumları

\begin{tabular}{lcc}
\hline Medeni durum & Frekans & Yüzde \\
\hline Bekâr & 1 & 3,4 \\
\hline Evli & 24 & 82,8 \\
\hline Boşanmış/ayrı & 2 & 6,9 \\
\hline Eşi ölmüş & 2 & 6,9 \\
\hline Toplam & $\mathbf{2 9}$ & $\mathbf{1 0 0}$ \\
\hline
\end{tabular}

Katılımcıların medeni durumları incelendiğinde büyük kısmı evlidir (\%82,8). Eşi ölmüş ve boşanmış/ayrı olanlar \%6,9 kısmı oluştururken, bekâr olanlar \%3,4 oranındadır. Evli olanlar araştırmanın en önemli kısmını oluşturmaktadır.

Tablo 4: Katılımcıların öğrenim durumları

\begin{tabular}{lcc}
\hline Öğrenim durumu & Frekans & Yüzde \\
\hline Okur-yazar değil & 2 & 6,9 \\
\hline Okuryazar ama okul mezunu değil & 3 & 10,3 \\
\hline İlkokul mezunu & 14 & 48,3 \\
\hline Ortaokul mezunu & 8 & 27,6 \\
\hline Lise ve dengi okul mezunu & 2 & 6,9 \\
\hline Toplam & $\mathbf{2 9}$ & $\mathbf{1 0 0}$ \\
\hline
\end{tabular}

Katılımcıların öğrenim durumları incelendiğinde en büyük kısmı $\% 48,3$ 'lük oran ile ilkokul mezunları oluşturmaktadır. Bunu \%27,6'lk 
kısım ile ortaokul mezunları, \%10,3'lük kısımla sadece okuryazar takip etmektedir. Bireylerin \%6,9'u okuma yazma bilmemekte ve \%6,9'luk k1sım lise ve dengi okul mezunundan oluşmaktadır. Görüldüğü üzere görüşülenlerin düşük eğitim seviyeleri dikkat çekici bir unsur olarak karşımıza çıkmaktadır. Bu bağlamda düşük eğitim, hem yoksulluğa hem de suçluluğa etki eden bir faktör olarak değerlendirilebilir.

Tablo 6: Katılımcıların ebeveynlerinin öğrenim düzeyleri

\begin{tabular}{lcccc}
\hline \multirow{2}{*}{$\begin{array}{l}\text { Ebeveynlerin öğrenim } \\
\text { durumu }\end{array}$} & \multicolumn{2}{c}{ Anne } & \multicolumn{2}{c}{ Baba } \\
\cline { 2 - 5 } & Frekans & Yüzde & Frekans & Yüzde \\
\hline $\begin{array}{l}\text { Okur-yazar değil } \\
\text { Okuryazar ama okul }\end{array}$ & 2 & 65,2 & 2 & 6,9 \\
$\begin{array}{l}\text { mezunu değil } \\
\text { İlkokul mezunu }\end{array}$ & 11 & 37,9 & 14 & 48,3 \\
$\begin{array}{l}\text { Ortaokul mezunu } \\
\text { Lise ve dengi okul mezunu }\end{array}$ & & & 8 & 27,6 \\
Toplam & $\mathbf{2 9}$ & $\mathbf{1 0 0}$ & $\mathbf{2 9}$ & $\mathbf{1 0 0}$ \\
\hline
\end{tabular}

Araştırmaya katılan bireyler büyük ölçüde öğrenim düzeyi düşük ailelerden gelmektedir. Bireylerin annelerinin eğitim düzeylerine bakıldığında büyük bir kısmının $(\% 55,2)$ hiç okula gitmediği görülmektedir. Bunu takiben annelerin \%37,9'u ilkokul, \%6,9'u ortaokul mezunudur. Diğer taraftan araştırmaya katılan bireylerin babaların öğrenim düzeyi annelere oranla daha yüksektir. Hiç okula gitmeyen babaların oranı \%6,9'dur. Bunu \%48,3 ilkokul mezunu, \%27,6 ortaokul mezunu, \%6,9 lise ve dengi okul mezunu takip etmektedir. Tabloya genel olarak bakıldığında ebeveynlerin öğrenim düzeyleri oldukça düşüktür. Görüşülen bireylerin öğrenim düzeylerinin, ebeveynlerinin öğrenim düzeylerine nispeten daha yüksek olduğu anlaşılmaktadır. 
Tablo 7: Katılımcıların bulundukları hanenin geliri

\begin{tabular}{lcc}
\hline Hane geliri & Frekans & Yüzde \\
\hline Geliri yok & 1 & 3,4 \\
\hline 250 TL ve aşağısı & 5 & 17,2 \\
\hline $251-500$ TL arası & 16 & 55,2 \\
\hline $501-750$ TL aras1 & 7 & 24,1 \\
\hline Toplam & $\mathbf{2 9}$ & $\mathbf{1 0 0}$ \\
\hline
\end{tabular}

Hane geliri yoksulluğun önemli göstergelerinden biridir. Çalışma açısından bu durum önemli bir araçtır. 250-50TL lira arası geliri olan hanelerin oranı $\% 55,2,500-750$ arası gelir ile 24,1 oranındadır. Bunu $250 \mathrm{TL}$ ve aşağısı \%17,2 ve geliri olmayan \%3,4 oranı takip etmektedir. Bu çerçevede görüşülen bireylerin büyük çoğunluğu asgari geçim düzeyinin altında kalmaktadır. Bunun içindir ki ekonomik göstergeler oranı suçluluğun belirlenmesinde önemlidir. Çünkü geliri olmayan ve bunu legal yollardan temin edemeyen birey illegal yollarla gelir sağlama yoluna gidecektir.

Tablo 8: Katılımcıların yaşadıkları hanenin hukuki durumu

\begin{tabular}{lcc}
\hline Hanenin durumu & Frekans & Yüzde \\
\hline Kira & 13 & 44,8 \\
\hline Kendi malı & 6 & 20,7 \\
\hline Ücretsiz & 8 & 27,6 \\
\hline Müşterek & 2 & 6,9 \\
\hline Toplam & $\mathbf{2 9}$ & $\mathbf{1 0 0}$ \\
\hline
\end{tabular}

Bu tablonun, çalışma açısından önemi, yoksulluğun derecesinin ölçülmesi olarak değerlendirilebilir. Katılımcıların çoğu günü birlik gelir elde eden ve daimi gelir için garantisi olmayanlardan oluşmaktadır. Bunun içindir ki oturulan evin hukuksal statüsü yoksulluğun belirlenmesinde 
araştırma açısından kayda değerdir. Bu çerçevede görüşmeye katılan bireylerin hemen hemen yarıs $\% 44,8$ 'i kirada, $\% 27,6$ 'lık kısmı ücretsiz ikamet etmektedirler. Bunu \%20,7 ile kendi malları ve \%6,9 ile müşterek ikametler takip etmektedir.

Tablo 9: Katılımcıların mesleki durumları

\begin{tabular}{lcc}
\hline Mesleki durum & Frekans & Yüzde \\
\hline Mesleğim yok & 5 & 17,2 \\
\hline Serbest meslek & 10 & 34,5 \\
\hline İşportacı & 10 & 34,5 \\
\hline İşçi (İnşaat Sektörü) & 2 & 6,9 \\
\hline İşçi (Hizmet Sektörü) & 1 & 3,4 \\
\hline Hamallık & 1 & 3,4 \\
\hline Toplam & $\mathbf{2 9}$ & $\mathbf{1 0 0}$ \\
\hline
\end{tabular}

Katılımciların sırasıyla mesleki durumları \%34,5'i serbest meslek yine $\% 34,5^{\prime} \mathrm{i}$ işportacı, \% 17,2'si mesleği olmayan, \%6,9'u inşaat işçisi $\% 6,9$ 'u ise hizmet sektöründen oluşmaktadır. Ayrıca görüşülenlerin \%3,4'ü hamallık yapmaktadır. Serbest meslekle uğraşanların, işportacılık yapanların dolayısıyla sokakta çalışan belli bir işyeri olmayan bireylerin büyük çoğunlukta olduğunu görmekteyiz. Yani bu tür meslek kategorilerine dâhil olanların birçoğunun belirli bir işi, dolayısıyla düzenli bir gelirleri de yoktur. Ayrıca bu kişilerin buldukları işlerin büyük bir bölümü, suçların en fazla işlendiği yerler olan, sokak ortamındadır.

İşsizlik faktörünün bireyin toplumsal değer ve normlara olan bağlılığını çözücü yönde etki yaptığını belirten Kızmaz (2003:282), işsizliğin bireylerde değer yitimi ve buna bağlı olarak norma uymama gibi etkileri olduğunu ifade etmektedir. Ayrıca işsizlikle birlikte derin dışlanmışlık hissinin bireylerde özsaygı yitimi, değersizlik hissi ve diğer karakter bozukluklarını ortaya çıkarmaktadır. Bu açıdan işsizlik faktörü önemli bir suç nedeni olarak görülebilir. 
Tablo 10: Katılımcıların kazançlarının geçimlerine yetmesi

\begin{tabular}{lcc}
\hline Elde edilen gelirin geçime yetmesi & Frekans & Yüzde \\
\hline Zorlukla geçiniyor & 11 & 37,9 \\
\hline Geçimini başkalarının yardımı ile sağlıyor & 13 & 44,8 \\
\hline Rahat bir şekilde geçiniyor & 5 & 17,2 \\
\hline Toplam & $\mathbf{2 9}$ & $\mathbf{1 0 0}$ \\
\hline
\end{tabular}

Görüşülen bireylerin ekonomik durumları veya elde ettikleri gelirin geçimlerine yetip yetmediği sorunu incelendiğinde, çok önemli bir kısmının $(\% 82,7)$ geçimini güçlükle sağlayabilen veya ancak başkalarının yardımıyla geçinebilen aileler oldukları görülmektedir. Sadece \% 17,2'lik bir kesim geçimini rahatça sağlamaktadır.

Tablo 11: Katılımcıların cezaevine girmeden önce yaşadığı hanenin mevcudu

\begin{tabular}{lcc}
\hline Hane halkı mevcudu & Frekans & Yüzde \\
\hline Tek yaşıor & 1 & 3,4 \\
\hline İki & 0 & 0 \\
\hline Üç & 3 & 10,3 \\
\hline Dört & 9 & 31,0 \\
\hline Beş & 4 & 13,8 \\
\hline Altı ve üstü & 12 & 41,4 \\
\hline Toplam & $\mathbf{2 9}$ & $\mathbf{1 0 0}$ \\
\hline
\end{tabular}

Görüşülen bireylerin yaşadıkları hanedeki birey sayısına sırasıyla bakacak olursak \%41,4 altı ve üstü kişi, \%31'i beş kişi, \%13,8'i dört kişi, \%10,3'ü üç kişi ve \%3,4'ü tek kişiden oluşmaktadır. Genel itibariyle suç işleyenlerin büyük çoğunluğu kalabalık ailelerin üyeleridir. Yani hane halkı mevcudu altı ve üstü bireyden oluşan hanelerin büyük çoğunluğunda on ve üzeri birey yaşamaktadır. 
Yoksulluk ve Suç Illișkisinin Sosyolojik Analizi: Bir Referans Çerçevesi (Elazığ Örneği)

Tablo 12: Katılımcıların yaşadıkları yere göç etme durumu

\begin{tabular}{lccc}
\hline Göç durumu & Frekans & Yüzde & Geçerli Yüzde \\
\hline Göç olmadı & 19 & 65,5 & 65,5 \\
\hline Elazı̆̆ köy/ilçe & 5 & 17,2 & 17,2 \\
\hline Başka ilden & 4 & 13,8 & 13,8 \\
\hline Başka ilin köy/ilçesi & 1 & 3,4 & 3,4 \\
\hline Toplam & $\mathbf{2 9}$ & $\mathbf{1 0 0}$ & $\mathbf{1 0 0}$ \\
\hline
\end{tabular}

Görüşülen bireylerin \%65,5’i göç olayını yaşamamıştır. Bulundukları yere göç edenlerin \%17,2' lik kısmı Elazığ köy ve ilçelerinden, \%13,8’i başka illerden ve \%3,4'ü başka ilin köy ve ilçelerinden göç etmişlerdir. Bu çalışmada daha çok araştırma alanının yerli sakinleri üzerinden hareket edildiğinden dolayı göç olayının suç işlemedeki etki derecesini analiz etmek yetersiz görülmektedir. Ancak ifade etmek gerekir ki artan suç oranlarının temelinde göç faktörünün bulunduğu birçok araştırma sonuçlarında mevcuttur. Nitekim göç sonrası işsizlik ve ekonomik problemler, bireyler için dezavantaj oluşturmaktadır. Ancak bu çalışmada göç olayını deneyimlemeyenlerin çoğunlukta olduğu görülmektedir.

Tablo 13: Katılımcıların göç sonucu yaşadığı zorluklar

Göç sonucu yaşanılan zorluklar Frekans Yüzde Geçerli Yüzde

\begin{tabular}{lccc}
\hline Hiçbir zorlukla karşılaşmama & 1 & 3,4 & 90,0 \\
\hline Çevreye uyum problemleri & 4 & 13,8 & 10,0 \\
\hline Toplam & $\mathbf{5}$ & $\mathbf{1 7 , 2}$ & $\mathbf{1 0 0}$ \\
\hline Ekonomik sıkıntılar & 10 & 34,5 & \\
\hline Göç etmemiş & 19 & 65,5 & \\
\hline Toplam & $\mathbf{2 9}$ & $\mathbf{1 0 0}$ & \\
\hline
\end{tabular}


Bir önceki tabloda görüldüğü üzere görüşmecilerin büyük çoğunluğu göç olayını deneyimlememiştir. Ancak göç olayını deneyimleyenlerin göç sonrası yaşadığı zorluklar incelendiğinde 17,2'si ekonomik s1kıntıları olanlardan, \%13,8'i çevreye uyum problemi olanlardan, \% 3,4'ü hiçbir zorlukla karşılaşmayanlardan oluşmaktadır. Göç sonrası işsizlik ve ekonomik problemler yaşanan en önemli sorunlardır.

Tablo 14: Katılımcıların cezaevine giriş nedeni

\begin{tabular}{lcc}
\hline Cezaevine giriş nedeni & Frekans & Yüzde \\
\hline Adam öldürmek & 11 & 37,9 \\
\hline Hırsızlık & 2 & 6,9 \\
\hline Adam dövmek, yaralamak & 6 & 20,7 \\
\hline Irza geçmek ve sarkıntılık & 1 & 3,4 \\
\hline Uyuşturucu ile ilgili suçlar & 8 & 27,6 \\
\hline Yasadışı örgüt üyeliği & 1 & 3,4 \\
\hline Toplam & $\mathbf{2 9}$ & $\mathbf{1 0 0}$ \\
\hline
\end{tabular}

Görüşülen bireylerin cezaevine girme nedenleri, yani işledikleri suç durumu incelendiğinde en fazla \%37,9'luk oranla adam öldürmek, $\% 27,6$ 'lık oranla uyuşturucu ile ilgili suçlar, \%20,7'lik oranla adam dövmek ve yaralamak, \%6,9'luk oranla hırsızlık, \%3,4'lük oranla yasadış1 örgüt üyeliği ve yine \%3,4'lük oranla ırza geçmek suçlarından oluşmaktadır. ayrıca şunu da belirtmeliyiz ki görüşülen bireylerin gerçekleştirdiği eylemler 5237 sayılı Türk Ceza Kanuna göre suç sayılan eylemlerdir. Ancak ifade etmek gerekir ki bahsi geçen suç türlerinin sadece yoksullukla ilişkilendirilmemesi ancak yoksulluğun bu suçları işlemede etkisi olduğu göz ardı edilmemelidir. 
Tablo 15: Katılımciların cezaevine girmelerine neden olan etken

\begin{tabular}{lll}
\hline Yapılan eyleme neden olan etken & Frekans & Yüzde \\
\hline İssizlik & 1 & 3,4 \\
\hline Sosyal çevre & 3 & 10,3 \\
\hline Bilgisizlik/cahillik & 6 & 20,7 \\
\hline İş anlaşmazlığ 1 & 3 & 10,3 \\
\hline Yoksulluk & 15 & 51,7 \\
\hline Alkol alma & 1 & 3,4 \\
\hline Toplam & $\mathbf{2 9}$ & $\mathbf{1 0 0}$ \\
\hline
\end{tabular}

Görüşülen bireylerin suç işlemelerine neden olan etkenin ne olduğu sorulduğunda \%51,7'si yoksulluğun, \%20,7'si bilgisizliğin/cahilliğin, \%10,3'ü sosyal çevrenin, yine \%10,3'ü iş anlaşmazlığının, \%3,4'ü işsizliğin suç sayılan eylemleri gerçekleştirmelerine neden olduğunu belirtmektedirler. Tablodan da anlaşılacağı üzere çoğunlukla ekonomik sıkıntılardan dolayı bireylerin suç işledikleri görülmektedir. Görüşülenlerin "işimiz olsa, çocuklarımızı rahat geçindirseydik, yoksulluğun sıkıntıları bizi agresif davranışlar yapmaya itiyor" gibi ifadeleri suç eylemlerinde ekonomik faktörlerin göz ardı edilmemesi gerektiğini gözler önüne sermektedir.

Tablo 16: Katılımcıların cezaevi sonrası ekonomik durumlarındaki değişim

\begin{tabular}{lcc}
\hline Tahliye sonrası ekonomik durum & Frekans & Yüzde \\
\hline Hiçbir değişiklik olmadı & 3 & 10,3 \\
\hline Ekonomik olarak sıkıntılarım oldu & 20 & 69,0 \\
\hline Sabıkamdan dolayı iş bulamadım & 6 & 20,7 \\
\hline Toplam & $\mathbf{2 9}$ & $\mathbf{1 0 0}$ \\
\hline
\end{tabular}

Görüşülen bireylere tahliye olduktan sonra ekonomik durumlarında herhangi bir değişikliğin olup olmadığı sorunsalı incelendiğinde, 
\%69,9'u ekonomik sıkıntılarının olduğunu, \%20,7'sinin sabıkasından dolayı iş bulamadığını ve \%10,3'ü herhangi bir değişikliğin olmadığını belirtmektedir. Buradan hareketle cezaevine girmiş bir bireyin tahliye sonrası ekonomik sıkıntılarının olması muhtemeldir. Bu durum bireyin tekrar suç işleme potansiyeli açısından önemlidir.

Tablo 17: Katılımcıların yetiştikleri aile ortamına ilişkin dağılım

\begin{tabular}{lcc}
\hline Aile ortamını tanımlama & Frekans & Yüzde \\
\hline Bölünmüş aile & 2 & 6,9 \\
\hline Aile içi şiddet & 8 & 27,6 \\
\hline Alkol & 5 & 17,2 \\
\hline Ailenin ilgisizliği & 2 & 6,9 \\
\hline Ekonomik problemler & 11 & 37,9 \\
\hline İyi bir aile ortamı & 1 & 3,4 \\
\hline Toplam & $\mathbf{2 9}$ & $\mathbf{1 0 0}$ \\
\hline
\end{tabular}

Görüşülen bireylerin yetiştikleri aile ortamıyla ilgili bilgileri suçun işlenmesinde rol oynayan önemli unsurların ortaya çıkarılması açısından önemlidir. Bu çerçevede bireyler ailelerini, \%37,9'u ekonomik problemleri olan, \%27,6'sı aile içi şiddetin olduğu, \%17,2'si aile reisinin sürekli alkol aldığını, \%6,9'u bölünmüş bir aile ortamında yetiştiğini, yine 6,9 'u ailenin kendisiyle ilgilenmediğini ve son olarak \%3,4'ü iyi bir aile ortamına sahip olduğu şeklinde tanımlamaktadır.

Tablo 18: Katılımcıların gerçekleştirdiği eylemden pişmanlık durumu

\begin{tabular}{lcc}
\hline Gerçekleștirilen eylemden pişmanlık durumu & Frekans & Yüzde \\
\hline Evet & 26 & 89,7 \\
\hline Hayır & 3 & 10,3 \\
\hline Toplam & $\mathbf{2 9}$ & $\mathbf{1 0 0}$ \\
\hline
\end{tabular}


Görüşülen bireylerin büyük bir oranı \% 89,7'si işledikleri suçtan dolayı pişmanlık duyduklarını belirtmişlerdir. Pişmanlık duymadıklarını belirtenlerin oranı ise \% 10,3'tür. Bireyin suçu işlerken bu duruma düşüp düşmeyeceğinin ve bireylerin işledikleri suça verilen cezanın caydırıcılı̆̆ı açısından bu tablo önemlidir.

Tablo 19: Katılımcıların yaşadıklarından kimleri sorumlu tuttukları

\begin{tabular}{lcc}
\hline Sorumlular & Frekans & Yüzde \\
\hline Kendimi & 12 & 41,4 \\
\hline Ailemi & 6 & 20,7 \\
\hline Sosyal çevremi & 9 & 31,0 \\
\hline Mevcut düzeni & 1 & 3,4 \\
\hline Hiç kimseyi & 1 & 3,4 \\
\hline Toplam & $\mathbf{2 9}$ & $\mathbf{1 0 0}$ \\
\hline
\end{tabular}

Araştırmaya katılan bireylerin suç işlemelerinden \% 41,4’lük oranla kendilerini/kaderlerini, \%31'lik oranla sosyal çevrelerini, \% 20,7'lik oranla ailelerini, \%3,4'lük oranla hiç kimseyi ve yine \%3,4'lük oranla mevcut düzeni sorumlu tuttukları gözlenmektedir. Birinci sırada kadercilik anlayışının hâkim olduğu ve yoksulluğun kadercilikle içselleştirildiği ve bilinçaltına atıldığı bir durumdan bahsedilebilir. Sosyal çevrenin sorumlu tutulması durumu, arkadaş çevresinin kurbanı olma veya suçun öğrenilmesi durumu ile ilişkilendirilebilir. Ailelerini sorumlu tutan bireylerin çoğunluğu, ailelerin ilgisizliği ve ailelerince yeterince eğitim almalarına imkân sağlanmadığı kanaatindeler. 
Tablo 20: Katılımcların cezaevinde iken kendisine ve ailesine kimleri destek olduğunun dağılımı

\begin{tabular}{lcc}
\hline Yardım alınan kişi ve kurum & Frekans & Yüzde \\
\hline Hiç kimse & 2 & 6,9 \\
\hline Ailem (anne, baba, kardeş) & 18 & 62,1 \\
\hline Akraba ve komşularım & 7 & 24,1 \\
\hline Hayırsever Vakıf ve şahıslar & 2 & 6,9 \\
\hline Toplam & $\mathbf{2 9}$ & $\mathbf{1 0 0}$ \\
\hline
\end{tabular}

Görüşülen bireylerin cezaevinde iken ailesine ve kendisine, \%62,l'i ailesinin, \%24,1'i akraba ve komşularının, \%6,9'u hayırsever vakıf ve şahısların yardım ettiğini ve bireyler ailelerinin bu sayede geçimini sağladığını belirtmektedirler.

Tablo 21: Katılımcıların suçla ilişkilendirilmesinin doğruluğu durumu

\begin{tabular}{lcc}
\hline Yoksulların suçla ilişkisi & Frekans & Yüzde \\
\hline Evet, doğru & 24 & 82,8 \\
\hline Hayır, doğru değil & 4 & 13,8 \\
\hline Bilmiyorum & 1 & 3,4 \\
\hline Toplam & $\mathbf{2 9}$ & $\mathbf{1 0 0 , 0}$ \\
\hline
\end{tabular}

Yoksulluk bireylerin kötü mesken şartlarını ve bu tür yerlerde ikamet etmesini zorunlu kılmaktadır. Bu zorunluluk bireylerin, bu tür ikamet yerlerine sığınmış suçlularla daimi temas etmelerine neden olur. Yani yoksulluk suç üzerinde ya doğrudan ya da dolaylı yoldan etki etmektedir. Buradan hareketle görüşülen bireylerin, yoksulların suçla ilişkilendirilmesi durumunu incelediğimizde $\% 82,8$ 'i evet, doğru buluyorum, 
\%13,8'i hayır, doğru bulmuyorum, \%3,4 bilmiyorum cevabını vermişlerdir. Bu veriler yoksulluğun ve yoksulluğun getirdiği dezavantajların içselleştirildiğini göstermektedir.

Tablo 22: Katılımcılara göre yoksulluğun suç işleme eyleminde etki durumu

\begin{tabular}{lcc}
\hline Yoksulluğun suçu etkileme durumu & Frekans & Yüzde \\
\hline Çok etkili & 14 & 48,3 \\
\hline Etkili & 10 & 34,5 \\
\hline Az etkili & 5 & 17,2 \\
\hline Toplam & $\mathbf{2 9}$ & $\mathbf{1 0 0}$ \\
\hline
\end{tabular}

Görüşülen bireyler, yoksulluğun suç üzerinde $\% 48,3$ çok etkili, $\% 34,5$ etkili, \%17,2 az etkili olduğunu söylemektedirler. Bu açıdan görüşülenlerin büyük çoğunluğu $(82,8)$ suç işlemelerinde yoksul olmalarının etkili olduğunu düşünmektedir. Nitekim bireylerle yapılan mülakat tarzı sohbetlerde de işledikleri suçların genelde yoksullukla ilişkili olduğunu belirtmeleri dikkatlerden kaçmamıştır. Bu çerçevede yoksul bireylerin genelde, olumsuz koşullar içeren bölgelerde ikamet ettikleri, sağlıksız şartlarda çalıştıkları düşünülecek olursa bireylerin hukuk dışı eylemlere yönelmeleri kaçınılmaz olabilmektedir.

Tablo 23: Katılımcılara göre suçu önlemenin en etkili yolu

\begin{tabular}{lcc}
\hline Suçu önlemenin yolu & Frekans & Yüzde \\
\hline Caydırıcı cezaları & 3 & 10,3 \\
\hline Eğitimle & 10 & 34,5 \\
\hline Ekonomik refahla & 10 & 34,5 \\
\hline Dini eğitimle & 6 & 20,7 \\
\hline Toplam & $\mathbf{2 9}$ & $\mathbf{1 0 0}$ \\
\hline
\end{tabular}


Görüşülen bireylere göre suçu önlemenin en etkili yolu suçla mücadelede ve bireylerin nasıl bir beklenti içerisinde olduklarının incelenmesi açısından önemlidir. Bu çerçevede, görüşülen bireylerin $\% 34,5^{\prime} \mathrm{i}$ eğitimle, yine $\% 34,5$ ekonomik refahla suçun önleneceği kanaatindeler. Bunu \%20,7 ile dini eğitimin ve \%10,3 ile caydırıcı cezalar takip etmektedir. Bu açıdan eğitim ve ekonomi faktörü suçun önlenmesinde büyük önem taşımaktadır. Suçu önlemede etkili faktörlerden biri olarak eğitim, toplumsallaşma sürecinin en önemli belirleyicisi konumundadır. Bu açıdan eğitim bireyin bütün yaşamı üzerinde etkili olan davranış kazanma, davranış geliştirme, davranış değiştirme gibi süreçlerini kapsayan veya kişiliğin gelişimine yardımcı olan ve bu çerçevede bireyi hayata hazırlayan, mevcut değer ve normları öğreterek onu topluma hazırlayan bir süreç olarak tanımlanabilir. Aynı zamanda eğitimin sosyal sermaye ve diğer (ekonomik, kültürel) sermaye boyutlarını olumlu yönde tetikleyen bir unsur olduğu göz önüne alındığında, eğitimin suçu önlemedeki işlevi daha iyi anlaşllacaktır.

Tablo 24: Katılımciların dindarlık durumu

\begin{tabular}{lcc}
\hline Dindarlık durumu & Frekans & Yüzde \\
\hline Çok dindar & 1 & 3,4 \\
\hline Dindar & 12 & 41,4 \\
\hline Az dindar & 11 & 37,9 \\
\hline Dindar değil & 5 & 17,2 \\
\hline Toplam & $\mathbf{2 9}$ & $\mathbf{1 0 0}$ \\
\hline
\end{tabular}

Dinin, birey üzerinde belirli ölçülerde bir denetim ve kontrol mekanizması olarak işlev gören yapısı, din olgusu ile suç arasındaki ilişki noktasını oluşturmaktadır. Din olgusu bireyin kaderci bir yapıya bürünmesi ve bu çerçevede konumuz açısından yoksulluğun, kendi kaderi olduğunu kabullenip tevekkül etmesi yoksulluğun getirdiği acıları azaltıcı bir etki yapmaktadır. Bu nedenle bireyin dindarlık durumunun, suç 
işleyip işlememesinde önemli bir değişken olacağ 1 tahmin edilmektedir. Görüşülen bireylerin çoğunluğu \%41,4'ü dindar, bunu \%37,9 ile az dindar, \%17,2 ile dindar değil ve \%3,4 ile çok dindar takip etmektedir.

Kızmaz’ın 2010 yılında Din ve Suç: Cezaevinde Hükümlü Bulunan Bazı Suçluların Dindarlık Durumları adlı çalışmasında, suçluların güçlü bir dindarlık düzeyine sahip olmadıklarına ilişkin elde edilen bu bulgular, dindarlık ve suç arasındaki ilişki konusunda belirli düzeyde bir çıkarsamada bulunmamızı kolaylaştırdığı ifade edilebilir. Burada, Kızmaz (2010: 52) suçluların cezaevi öncesi güçlü dindarlık durumuna sahip olmamalarının onların suç işlemelerinde etkili olduğunu belirtmektedir. Yine Taş ve Gürler'in, (2010: 12-15). Din ve Suç İlişkisi Üzerine Uygulamalı Bir Araştırma adlı çalışmasında çıkan sonuçlar çerçevesinde, din veya dindarlık olgusunun, suçluluğu çözümlemede işlevsel rol oynadığ 1 görülmektedir. Araştırmada ele alınan dindarlık değişkenleri çerçevesinde gerçekleşen oransal dağılımlara bakıldığında suçluların dindarlık düzeyi açısından olumsuz bir görünüm sergiledikleri anlaşılmaktadır.

Tablo 25: Katılımciların gelecekten beklentisi

\begin{tabular}{lcc}
\hline Gelecekten beklenti & Frekans & Yüzde \\
\hline Ekonomik olarak iyi olmak & 16 & 55,2 \\
\hline Huzur ve güven içinde yaşamak & 11 & 37,9 \\
\hline İyi bir meslek sahibi olmak & 1 & 3,4 \\
\hline Çocuklarımın eğitimi & 1 & 3,4 \\
\hline Toplam & $\mathbf{2 9}$ & $\mathbf{1 0 0}$ \\
\hline
\end{tabular}

Beklentisi olmayan bireylerin, beklentisi olan bireyler oranla daha normsuz bir yaşam tarzları olduğu söylenebilir. Bunun sebebi bireyler iyi bir ortamda yaşıyor ve ihtiyaçları gideriliyorsa, bu imkânlardan yoksun kalmak istemez ve bunu oluşturacak hareket ve davranışlara yönelmezler. Aksi halde, karşılaşacakları olumsuz bir ortam, onları istenmedik 
sonuçlara sürükleyebilir. Buradan hareketle görüşülenlerin gelecekten beklentilerini inceleyecek olursak; \%55,2'si ekonomik olarak iyi olmak, \%37,9'u huzur ve güven içinde yaşamak, \%3,4'ü iyi bir meslek sahibi olmak ve yine \%3,4'ü çocuklarının eğitimidir. Buradan hareketle tabloya göz atacak olursak, ekonominin önemi yine karşımıza çıkmaktadır. İkinci sırada yer alan huzur ve güven içinde yaşamak, hem ailevi hem de ikamet yeri açısından değerlendirilebilir. Yoksul insanların, sağlıksız ve olumsuz mekânlarda ikamet ettikleri gerçeği burada karş1mıza çıkmaktadır. Çocukların eğitimini ikinci plana atan bu bireylerin, öncelikle ekonomik olarak iyi olmanın çabasında oldukları aşikârdır.

\section{Sonuç ve Değerlendirme}

Ülkemizde yaşanılan toplumsal dönüşümlerin yarattığı kırılmalar, lüks tüketim alışkanlıklarının yaygınlaşması, sosyal eşitsizlikler suça neden olabilen faktörler arasında gösterilebilir. Bu bağlamda bir tarafta her istediğine fazlasıyla sahip olanlar, diğer tarafta temel ihtiyaçlarını bile karşılayamayanların oluştuğu toplumsal yapılarda suçun kaçınılmaz bir olgu olarak varlığını sürdüreceği söylenebilir.

$\mathrm{Bu}$ açıdan yoksulluğun suç eğilimini hızlandıracağını da söyleyebiliriz. Çünkü istatistiksel sonuçlara baktığımızda suçluların büyük oranda kentlerin gecekondu bölgelerinden çıkması, ekonomik açıdan zayıf olmanın, suçluluğun temel sebebi olmamasına rağmen, suçluluğu artırıcı bir rol oynadığı kanaatini uyandırmaktadır.

Tüm bu bilgiler ve bulgular ışığında, Elazığ ilinde yapılan bu çalışmada elde edilen verileri şu şekilde belirtmek mümkündür. Araştırmaya katılanların tamamı erkeklerden oluşmakta ve bunların büyük çoğunluğunun $(\% 82,8)$ evli olduğu görülmektedir.

Suç çözümlemelerinde önemli değişkenlerden biri, yaş faktörüdür. Çünkü suç işleme oranları, yaş gruplarına göre değişkenlik arz etmektedir Araştırılan bireyler arasında en büyük yaş grubunu \% 44,8 ile 3140 arası yaş grubu oluşturmaktadır. Bu grubu 41-50 yaş grubu $(\% 24,7)$ takip etmektedir. 
Görüşülen bireyler arasında yükseköğrenim görmüş kişi sayısı oldukça azdır. Bu bireyler arasında ilkokul mezunları ağırlıkta olmakla birlikte, bu grup okuryazar olmayanlar ve diplomasizlarla birlikte en büyük kesim oluşturmaktadır. Diğer yandan görüşülen bireylerin ebeveynlerinin öğrenim düzeyleri oldukça düşüktür. Görüşülen bireylerin öğrenim düzeylerinin, ebeveynlerinin öğrenim düzeylerine nispeten daha yüksek olduğu anlaşılmaktadır. Yani araştırmaya katılanların büyük çoğunluğu öğrenim düzeyi çok düşük ve çocuk sayısı oldukça yüksek ailelerden gelmektedir. Görüşülen bireyler çoğunlukla çocukluk yıllarını yoksullukla geçirmiş ve isteklerine büyük ölçüde sahip olamamış kimselerdir.

Hane geliri yoksulluğun önemli göstergelerindendir. Bu çerçevede araştırmaya katılanların \%55,2'si 250-50TL lira arası geliri bulunmaktadır. Bu çerçevede görüşülen bireylerin büyük çoğunluğu asgari geçim düzeyinin altında kalmaktadır. Bunun içindir ki ekonomik göstergeler oranı suçluluğun belirlenmesinde önemlidir. Çünkü geliri olmayan ve bunu legal yollardan temin edemeyen birey illegal yollarla gelir sağlama yoluna gidecektir. Yine birçok araştırma sonucunda, ekonomik durumu kötü olan sosyal sınıfa mensup bireylerin, gelir düzeyi yüksek sınıflara göre daha fazla suç işledikleri sonucuna varılmıștır.

Görüşmeye katılan bireylerin oturdukları hanenin hukuksal statüsü yine yoksulluğun belirlenmesi açısından önemlidir. Görüşülen bireylerin çoğu, günü birlik gelir elde eden ve daimi gelir için garantisi olmayanlardan oluşmaktadır. Bunun içindir ki oturulan evin hukuksal statüsü yoksulluğun belirlenmesinde araştırma açısından kayda değerdir. Bu çerçevede görüşülenlerin hemen hemen yarısı \%44,8’i kirada oturmaktadır.

Görüşülen bireylerin mesleki durumları $\% 34,5$ 'i serbest meslek yine \%34,5’i işportacı, \% 17,2'si mesleği olmayan, \%6,9'u inşaat işçisi \%6,9’u ise hizmet sektöründen oluşmaktadır. Serbest meslekle uğraşanların, işportacılık yapanların dolayısıyla sokakta çalışan belli bir işyeri olmayan bireylerin büyük çoğunlukta olduğunu görmekteyiz. Yani bu tür meslek kategorilerine dâhil olanların birçoğunun belirli bir işi, dolayısıyla 
düzenli bir gelirleri de yoktur. Ayrıca bu kişilerin buldukları işlerin büyük bir bölümü, suçların en fazla işlendiği yerler olan, sokak ortamındadır.

Görüşülen bireylerin ekonomik durumları veya elde ettikleri gelirin, geçimlerine yetip yetmediği sorunu incelendiğinde, çok önemli bir kısmının $(\% 82,7)$ geçimini güçlükle sağlayabilen veya ancak başkalarının yardımıyla geçinebilen aileler oldukları tespit edilmiştir. Görüşülen bireylerin yaşadıkları hanedeki birey sayısına sırasıyla bakacak olursak genel itibariyle suç işleyenlerin büyük çoğunluğu kalabalık ailelerin üyeleridir.

Araştırmaya katılan bireylerin büyük çoğunluğu \%65,5’i göç olayını yaşamamıştır. Göç edenlerin göç sebebi ise genellikle iş bulmak ve daha iyi bir yaşam ümidi, dolayısıyla ekonomik kaygılardır. Bununla birlikte görüşülen bireylerin göç sonrası yaşadığı zorluklar incelendiğinde, büyük çoğunluğun göç sonrası işsizlik ve ekonomik problemleri olduğuna tanık olunmuştur.

Görüşülen bireylerin suç işlemelerine neden olan etkenin ne olduğu sorulduğunda yoksulluğun, suç sayılan eylemleri gerçekleştirmelerine neden olduğunu görülmektedir. Buna işsizliği de katacak olursak çoğunlukla ekonomik sıkıntılardan dolayı bireylerin suç işledikleri gözlemlenmektedir.

Bireylere tahliye olduktan sonra ekonomik durumlarında herhangi bir değişikliğin olup olmadığı sorunsalı incelendiğinde, çoğunluğunun ekonomik sıkıntılarının olduğu tespit edilmiştir. Buradan hareketle cezaevine girmiş bir bireyin tahliye sonrası ekonomik sıkıntılarının olması muhtemeldir. Bu durum bireyin tekrar suç işleme potansiyeli açısindan önemlidir.

Görüşülen bireylerin yetiştikleri aile ortamıyla ilgili bilgileri suçun işlenmesinde rol oynayan önemli unsurların ortaya çıkarılması açısından önemlidir. Bu çerçevede bireylerin, \%37,9'u ekonomik problemleri olan, \%27,6'sı aile içi şiddetin olduğu, \%17,2'si aile reisinin sürekli alkol aldığını, \%6,9'u bölünmüş bir aile ortamında yetiştikleri tespit edilmiştir. Genel itibariyle suç işleyen bireylerin büyük çoğunluğu sorunlu aile ortamlarında yetiştikleri gözlemlenmiştir. 
Hükümlülerin işledikleri suçtan dolayı pişmanlık durumlarına bakıldığında ise; suçluların büyük çoğunluğu işledikleri suçtan dolayı pişmanlık duyduklarını belirtmişlerdir.

Araştırmadan elde edilen bir başka sonuç araştırmaya katılan bireylerin tüm bu yaşananlarda kimleri sorumlu tuttuğu sorunsalıdır. Araştırmaya katılan bireylerin suç işlemelerinden \% 41,4'lük oranla kendilerini/kaderlerini, \%31'lik oranla sosyal çevrelerini, \% 20,7'lik oranla ailelerini, \%3,4'lük oranla hiç kimseyi ve yine \%3,4'lük oranla mevcut düzeni sorumlu tuttukları gözlenmektedir. Birinci sırada kadercilik anlayışının hâkim olduğu ve yoksulluğun kadercilikle içselleştirildiği ve bilinçaltına atıldığ 1 bir durumdan bahsedilebilir.

Görüşülen bireylerin cezaevine düşmelerinden sonra ailelerinin ekonomik sorunları devam etmektedir. Ailelerinin ve kendilerinin geçimini sağlamada, yakın akrabalar, uzak akrabalar, komşu ve hayırsever vakıf ve şahısların yardımı sağlanmaktadır.

Görüşülen bireylerin, yoksulların suçla ilişkilendirilmesi durumunu incelediğimizde büyük çoğunluğun suç işleme eyleminde yoksulluğun çok etkili olduğu kanaati ortaya çıkmaktadır. . Bu çerçevede yoksul bireylerin genelde, olumsuz koşullar içeren bölgelerde ikamet etmeleri, sağlıksız şartlarda çalışmaları, çeşitli dışlama pratiklerine maruz kalmaları bireylerin hukuk dışı eylemlere yönelmelerini kolaylaştırıcı bir etki yaptığ 1 sonucuna ulaşılabilir.

Görüşülen bireyler suçu önlemenin en etkili yolunun, ekonomik refahla sağlanacağını belirtmektedirler. Aynı şekilde görüşülenlerin gelecekten beklentilerini büyük oranda, ekonomik olarak iyi olmak etrafında şekillenmektedir. Beklentisi olmayan bireyler, beklentisi olanlara göre daha tehlikelidir. Bunun sebebi bireyler iyi bir ortamda yaşıyor ve ihtiyaçları gideriliyorsa, bu imkânlardan yoksun kalmak istemez ve bunu oluşturacak hareket ve davranışlara yönelmezler. Aksi halde, karşılaşacakları olumsuz bir ortam, onları istenmedik sonuçlara sürükleyebilir. Buradan hareketle beklenti tablosundan çıkan sonuçlara göz atacak olursak, ekonominin önemi yine karşımıza çıkmaktadır. 
Özetle bu çalışmanın verileri ışığında sosyolojik bağlamda, yoksulluk ile suç arasında anlamlı bir ilişkinin olduğu sonucuna varılmıştır. $\mathrm{Bu}$ minvalde bazı suç işleyen insanların suç işleme nedenleri arasında yoksulluğun olduğu sonucu çıkmaktadır. Zira yoksul olmak suç işlemek için bir neden sayılamaz, bu tüm yoksulların suç işleyeceği sonucunu ortaya çıarır. Ancak suça yönelimde yoksulluk önemli bir etkendir. Araştırmada elde edilen veriler ışığında yoksulluk kişileri suça ittiği gibi, suç işlemek de kişileri daha da yoksullaştırmaktadır. Öte yandan yoksulluk, suç olgusunun meydana gelmesinde önemli olmakla birlikte tek basına suçu açıklamaktan yoksundur.

\section{Kaynakça}

Aydın, Derya, (2007). Küreselleşme ve Yoksulluk İlişkisinin Sosyolojik Analizi, (Yayınlanmamış Yüksek Lisans Tezi), Fırat Üniversitesi Sosyal Bilimler Enstitüsü, Elazığ.

Ayhan, İrem; Çubukçu, K.Mert (2007). "Suç ve Kent İlişkisine Ampirik Bakıș: Literatür Taraması”, Süleyman Demirel Üniversitesi Sosyal Bilimler Enstitüsü Dergisi Yıl: 3, Sayı: 5, 2007, 30-55.

Buğra, Ayşe (2005). "Yoksulluk ve Sosyal Haklar”, www.spf.boun.edu. tr/docs /STGP_Bugra.pdf, (Erişim Tarihi: 01.11.2011).

Cömertler, Necmiye (2004). “Kadın Penceresinden Yoksulluk”, IV. Aile Şurası Aile ve Yoksulluk Bildirileri, Editör: Rahime Beder Şen, Ankara: Başbakanlık Aile Araştırma Kurumu Başkanlığı Yay.

Dinler, Veysel ve İçli, Tülin (2012). “Suç Yoksulluk Etkiselliği (Isparta Cezaevi Örneği), idc.sdu.edu.tr/tammetinler/demokrasi/demokrasi48.pdf.

Dönmezer, S. (1994). Kriminoloji. İstanbul: Beta Basım Yayım Dağıtım Ehrlich, Isaac (1996). Crime, Punishment, and the Market for Offenses. Journal of Economic Perspective. Vol. 10, No. 1, pp. 43-67.

Erdoğan, Necmi (2002). "Yoksulları Dinlemek”, Yoksulluk Halleri, Türkiye’de Kent Yoksulluğunun Toplumsal Görünümleri, İstanbul: Demokrasi Kitaplığı Yay. 
Farnworth, Margaret ve Lieber, Michael J. (1989). "Strain Theory Revisited: Economic Goals, Educational Means, and Delinquency." AmericanSociological Review. Vol. 54 no. 2 pp. 263-74.

Giddens, Anthony (2008). Sosyoloji, İstanbul: Kırmızı Yay.

Işık, Esra, (2007). Kent Yoksulluğu, Sokak Çocukları ve Suç, (Yayınlanmamış Yüksek Lisans Tezi), Dumlu Pınar Üniversitesi Sosyal Bilimler Enstitüsü, Kütahya.

İçli, Tülin G. (1993). Türkiye’de Suçlular (Sosyal Kültürel ve Ekonomik Özellikleri), Ankara: Atatürk Kültür, Dil ve Tarih Kurumu Atatürk Kültür Merkezi Yayını Sayı:71.

Mehlum, Halvor; Karl Moene; Ragnar Torvik (2005). "Crime Induced Powerty Traps”, Journal of Development Economics 77, ss.325-340.

Kızılçelik S. ve Erjem Y. (1996). Açıklamalı Sosyoloji Sözlüğü, İzmir: Saray Kitabevleri.

Kızmaz, Zahir (2010), "Din ve Suç: Cezaevinde Hükümlü Bulunan Bazı Suçluların Dindarlık Durumları”, Sosyal Bilimler Araştırma Dergisi, Eylül, S. 16, ss.27-58.

Kızmaz, Zahir (2003), "Ekonomik Yapı ve Suç: Bazı Araştırma Bulguları Üzerine Genel Bir Değerlendirme” Firat Üniversitesi Sosyal Bilimler Dergisi, Cilt: 13, Say1: 2, ss.279-304.

Vold G. Bernard T. Snipes J. (2001). Thoeretical Criminology, 5. Press, New York: Oxford Pres.

Uzun, Ayşe Meral (2003). "Yoksulluk Olgusu ve Dünya Bankası", C.Ü. İktisadi ve İdari Bilimler Dergisi, Cilt 4, Say1 2, 2003.

Sokullu R. Füsun, "Suçun Nedenleri”, www.kriminoloji.com (E.T. 01.01.2012).

Taş, Kemaleddin; Gürler, Adem (2011), “Din ve Suç İlişkisi Üzerine Uygulamalı Bir Araştırma”, Journal of Islamic Research, 22(1).

Taylor, Blake (2006). "Poverty ve Crime: Fundamental Finance", ekonomi.temelfinans.com (E.T. 05.11.2011). 
Abstract: -A Sociological Analysis of The Relationship of Poverty and Crime (Case of Elazı $\breve{g}$ )- A number of factors that influence crime in social life can be mentioned. Economic situation and poverty, crime on one of the elements is highly effective. Many sociologists, criminologists and economists have acknowledged that an affective relationship between poverty and crime. From this perspective, all interest of the social sciences crime, especially the causes and consequences in terms of the economic dimension is a significant phenomenon which cannot be ignored. However, this study instead of a definitive causal relationship between crime and poverty, poverty, crime has a positive impact on the conviction that has brought. In this manner, for the purpose of uncovering the relationship of crime and poverty, of Elazığ province, Aksaray, Hicret, and Sanayi neighborhoods in prison for various crimes before substituting in the questionnaire with 29 individuals reviewed. In addition, the area has been influential in the shaping of the observations obtained in the study. Individuals out of prison and I went to jail before the next general situation, they were asked questions about their economic status and commit the crimes. The data obtained was interpreted to determine the relationship between poverty and crime of explore.

Key Words: Poverty, Crime, Socio-economic Status, Poverty-crime relationship, Elazı ̆. 